Klop, H., Dongen, S. van, Onwuteaka-Philipsen, B., Rietjens, J., Veer, A. de, Francke, A., Gootjes, J. Samen sterker: consultatie verbetert palliatieve zorg voor dak- en thuislozen.

Pallium: 2018, 20(1), 16-19

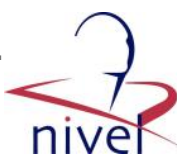

\begin{tabular}{|l|l|}
\hline $\begin{array}{l}\text { Postprint } \\
\text { Version }\end{array}$ & 1.0 \\
\hline Journal website & $\frac{\text { https://mijn.bsl.nl/samen-sterker-consultatie-verbetert-palliatieve-zorg-voor-dak- }}{\text { en/15484836 }}$ \\
\hline Pubmed link & $\underline{ }$ \\
\hline DOI &
\end{tabular}

This is a NIVEL certified Post Print, more info at http://www.nivel.eu

\title{
Samen sterker Consultatie verbetert palliatieve zorg voor dak- en thuislozen
}

\author{
DOOR HANNA KLOP, SOPHIE VAN DONGEN, BREGJE ONWUTEAKA-PHILIPSEN, JUdITH \\ RIETJENS, ANKE DE VEER, ANNEKE FRANCKE EN JAAP GOOTJES
}

Hanna Klop is junior onderzoeker bij het VU medisch centrum.

Sophie van Dongen is junior onderzoeker bij het Erasmus Medisch Centrum.

Bregje Onwuteaka-Philipsen is professor Levenseindeonderzoek bij het VUmc en voorzitter van bestuur Expertisecentrum Palliatieve Zorg bij het VUmc.

Judith Rietjens is assistent professor Maatschappelijke Gezondheidszorg bij het Erasmus

Medisch Centrum.

Anke de Veer is senior onderzoeker bij het NIVEL.

Anneke Francke is programmaleider NIVEL, bijzonder hoogleraar Verpleging en verzorging in de laatste levensfase bij het VUmc en lid van bestuur Expertisecentrum Palliatieve Zorg bij het VUmc.

Jaap Gootjes is algemeen directeur en bestuurder van Hospice Kuria.

Palliatieve zorg voor ernstig zieke mensen die dak- en thuisloos zijn, wordt vaak pas laat of helemaal niet geboden. Om dit te verbeteren, is in Amsterdam een samenwerking tussen hospice en maatschappelijke opvang opgezet. De auteurs hebben onderzocht of hier elders ook behoefte aan is.

In Amsterdam is vijf jaar geleden een samenwerking gestart tussen hospice Kuria en de maatschappelijke opvang van HVO Querido en het Leger des Heils.

Hulpverleners uit de maatschappelijk opvang kunnen advies vragen aan verpleegkundigen van hospice Kuria over de palliatieve zorg voor dak- en thuisloze mensen. Ook kunnen zij een verpleegkundige van Kuria inschakelen als ze moeite hebben met het herkennen van de palliatieve fase bij de dak- of thuisloze. De verpleegkundige van Kuria gaat dan op bezoek bij de patiënt en geeft adviezen. Hierdoor kan de patiënt zo lang mogelijk in zijn vertrouwde omgeving blijven. Als de zorg erg intensief is, kan de patiënt opgenomen worden in Kuria.

Daar adviseren de hulpverleners van de maatschappelijke opvang over de omgang met de patiënt. Deze hulpverleners kennen de persoon vaak al langere tijd, waardoor zij meer inzicht kunnen geven in historie, gedrag en behoeften van de persoon (zie kader 1 met een praktijkvoorbeeld).

Door deze wederzijdse uitwisseling - in dit artikel verder 'consultatie' genoemd zijn zowel de professionals die werkzaam zijn bij de maatschappelijke opvang, als professionals die werkzaam zijn in het hospice of op een verpleegafdeling beter toegerust voor het geven van goede palliatieve zorg aan mensen die dak- of thuisloos zijn. Daarnaast is de patiënt die dak- of thuisloos is, al bekend met en bij het hospice. 
Klop, H., Dongen, S. van, Onwuteaka-Philipsen, B., Rietjens, J., Veer, A. de, Francke, A., Gootjes, J. Samen sterker: consultatie verbetert palliatieve zorg voor dak- en thuislozen. Pallium: 2018, 20(1), 16-19

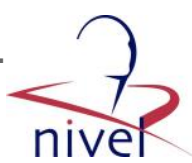

\section{ONDERZOEK}

In ons onderzoek keken we of er behoefte is aan consultatie, op welke wijze deze dan het best vormgegeven zou kunnen worden en of hiernaast nog andere initiatieven nodig zijn om de zorg te verbeteren.

Als onderdeel van het project zijn er focusgroepbijeenkomsten gehouden met 19 professionals en 15 personen die dak- of thuisloos zijn en die verbleven op een verpleegafdeling, zie ook kader 2 . In de volgende paragrafen beschrijven we de resultaten van deze focusgroepen. We bespreken wat palliatieve zorg voor deze doelgroep ingewikkeld maakt, wat mensen die dak- of thuisloos zijn vinden van het idee van consultatie, of professionals behoefte hebben aan consultatie, welke uitdagingen er zijn voor de opzet ervan en wat er naast consultatie verder nog nodig is voor goede palliatieve zorg.

\section{Wat maakt palliatieve zorg voor mensen die daken thuisloos zijn zo ingewikkeld?}

Uit de focusgroepen bleek dat personen die dak- of thuisloos zijn in de palliatieve fase complexe problemen en specifieke zorgbehoeften hebben. Zij hebben vaak een lange historie van lichamelijke aandoeningen, in combinatie met problemen met onder meer huisvesting, inkomen en schulden, verslaving, psychiatrische aandoeningen en/of een (licht) verstandelijke beperking. Ook is hun ziekteverloop meestal onvoorspelbaar. Het is vaak moeilijk in te schatten hoe lang ze nog te leven hebben.

\section{[KADER 1]}

Aan het einde van het leven zijn er vaak overgangen tussen settingen. Het kan voorkomen dat iemand uit de doelgroep eerst in de nachtopvang zit, dan een spoedopname in een ziekenhuis krijgt en vervolgens naar een hospice of verpleegafdeling gaat.

Personen die zelf dak- en thuisloos zijn, benoemden dat zij ervaren dat veel professionals niet genoeg weten van specialistische (medische) zorg en de kenmerken van de doelgroep. Vaak weten professionals op één gebied veel van problematiek, maar op een ander gebied weer niet.

In de laatste levensfase is verslaving aan alcohol en/ of drugs vaak nog aanwezig, pijnbestrijding kan dan lastig zijn. Ook is er vaak gedrag als agressie, zorgmijding en weggaan wanneer men wil. Dit is gedrag waar professionals van buiten de maatschappelijke opvang of GGZ minder ervaring mee hebben. Verder komt het vaak voor dat een iemand die dak- of thuisloos is, weinig contact met familie en vrienden heeft.

\section{Wat vinden mensen die dak- en thuisloos zijn van consultatie?}

Deelnemers die dak- en thuisloos zijn, kwamen tijdens de focusgroepen vaak met praktische invullingen van de consultatie, zoals een maatschappelijk werker of een belangenbehartiger die hen helpt hun behoeften te verwoorden. Daarnaast zagen zij consultatie als een goed middel om professionals te trainen op het tonen van begrip en aandacht. Niet alle zorgverleners kunnen dat volgens hen even goed of hebben daar voldoende tijd voor; vooral artsen en in mindere mate verpleegkundigen werden in dit verband genoemd. 
Klop, H., Dongen, S. van, Onwuteaka-Philipsen, B., Rietjens, J., Veer, A. de, Francke, A., Gootjes, J. Samen sterker: consultatie verbetert palliatieve zorg voor dak- en thuislozen. Pallium: 2018, 20(1), 16-19

Mensen die dak- of thuisloos zijn, willen graag serieus genomen worden, ook willen zij zorg die bij hen past. Als professionals meer met elkaar gaan samenwerken, zijn er volgens hen meer mogelijkheden om passende zorg te bieden doordat professionals veel van elkaar kunnen leren.

\section{[KADER 2]}

\section{Hebben professionals behoefte aan consultatie?}

Professionals wezen op de behoefte aan consultatie over de omgang met problemen die spelen in de laatste levensfase van de doelgroep. Professionals zagen de meerwaarde van consultatie bij het delen van specifieke expertise en kennis waarover zij niet of nauwelijks beschikken, en als middel om medische en maatschappelijke vakgebieden en professionals te verbinden. Ook bleek dat professionals behoefte hebben aan het beter leren herkennen van de palliatieve fase bij een dak- of thuisloze patiënt.

Deze consultatiefunctie kan professionals leren om de palliatieve fase beter te herkennen of er beter mee om te gaan. Daarnaast bleek dat veel professionals behoefte hebben aan meer samenwerking en het bundelen van kennis vanwege de complexiteit van de problematiek in deze doelgroep. Deze samenwerking kan daarnaast laten zien welke kennis nog moet worden ontwikkeld. Professionals in de focusgroepen waren het erover eens dat het doel van consultatie moet zijn dat iemand die dak- of thuisloos is zo lang mogelijk op een vertrouwde plek verblijft. Ook kan consultatie bijdragen aan bewustwording en het bespreekbaar maken door voorlichting en/of scholing, coaching bij het leveren van maatwerk en coördinatie van de zorg door gericht door te verwijzen.

\section{Hoe kan deze consultatie het best worden ingevuld?}

Professionals noemden vaak dat de invulling van palliatieve zorg voor dak- en thuisloze mensen per stad, professional en organisatie verschilt. Veel is afhankelijk van de al aanwezige expertise en van de organisatie. Het is belangrijk de consultatie hierop aan te passen. Er moet dus op lokaal niveau worden geïnventariseerd wat er nodig is aan consultatie en hoe dit gefinancierd wordt. Een aandachtspunt is dat deze consultatie wordt afgestemd met bestaande consultatiefuncties, zoals die van het IKNL. Dat kan met name door deze consulenten basiskennis bij te brengen over de doelgroep in de palliatieve fase, en door huidige consultatiefuncties te informeren over de specifieke functie van de consultatie rondom palliatieve zorg voor dak- en thuislozen. Hoe dit in de praktijk gaat werken, moet blijken uit vervolgonderzoek. Uit de focusgroepen kwam een beeld naar voren met verschillende kenmerken die een goede consulent idealiter heeft. Een goede consulent verbindt organisaties en vakgebieden, neemt initiatief, vertegenwoordigt meerdere organisaties en kent de praktijk van binnenuit. Een laagdrempelige consulent die flexibel bereikbaar is, is gezien de problematiek en het leefritme van de doelgroep van meerwaarde. Kader 3 geeft een indruk van genoemde onderwerpen waarbij regelmatig kennis ontbreekt en waar een consulent zou kunnen helpen. De vraagstukken rond implementatie en financiering worden in een vervolgproject uitgewerkt. 
Klop, H., Dongen, S. van, Onwuteaka-Philipsen, B., Rietjens, J., Veer, A. de, Francke, A., Gootjes, J. Samen sterker: consultatie verbetert palliatieve zorg voor dak- en thuislozen. Pallium: 2018, 20(1), 16-19

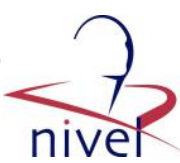

\section{[KADER 3]}

\section{Wat is er naast consultatie nodig voor goede palliatieve zorg aan deze doelgroep?}

Mogelijkheden voor consultatie van andere zorgverleners bleek niet het enige dat professionals wensen. Ook een kennisplatform waar kennis met andere professionals wordt gedeeld werd genoemd door deelnemende professionals in de focusgroepen. Consultatie is vaak pas nodig in de palliatieve fase van een individuele patiënt. Daarom kan een kennisplatform er volgens professionals voor zorgen dat zij in het algemeen beter geïnformeerd zijn en minder kennis zelf hoeven te ontwikkelen. Voor mensen die dak- en thuisloos zijn, bleek daarnaast een belangenbehartigersfunctie belangrijk. Een belangenbehartiger, bij voorkeur een ervaringsdeskundige, zou hen wanneer zij ernstig ziek zijn bij kunnen staan, bijvoorbeeld in contacten met zorgverleners.

\section{CONCLUSIE}

Er is behoefte aan consultatiemogelijkheden over de palliatieve zorg voor mensen die dak- of thuisloos zijn. Professionals die in de maatschappelijke opvang zorgen voor ongeneeslijk zieke mensen die dak- en thuisloos zijn, willen meer weten over de palliatieve zorgmogelijkheden. Professionals die in hospices, verpleeghuizen en ziekenhuizen palliatieve zorg bieden aan mensen die dak- of thuisloos zijn, hebben op hun beurt behoefte aan advies over de omgang met deze doelgroep. Ook mensen die dak- of thuisloos zijn, zien consultatie als een middel om de palliatieve zorg beter aan te laten sluiten bij de specifieke individuele behoeften en vaak complexe problematiek.

\section{KADERS}

Kader 1. Praktijkvoorbeeld consultatie

De 54-jarige Harry verblijft al ruim vier jaar bij De Aak, een maatschappelijke opvang van HVO Querido. Zijn persoonlijk begeleidster, een maatschappelijk werkster, is bekend met zijn lange geschiedenis van dakloosheid en ziet dat hij de laatste tijd vaak ziek is. Harry vermagert sterk, hoest veel en geeft aan dat hij erg moe is. Zijn situatie blijft verslechteren en de GGD-arts en het team van de maatschappelijke opvang bespreken zijn situatie. Zij geven aan dat zij verwachten dat Harry waarschijnlijk niet langer dan zes maanden te leven heeft. Harry geeft aan dat hij graag bij de Aak wil blijven, zolang als dat kan. De begeleidster belt een verpleegkundige van Kuria en legt de situatie uit. De verpleegkundige van Kuria gaat daarna op bezoek bij Harry. Ze geeft de begeleidster, de GGD-arts en de verpleegkundigen adviezen over palliatieve zorg, waardoor Harry zo lang mogelijk op zijn vertrouwde verblijfplaats kan blijven. Als Harry zieker wordt, gaat hij naar Hospice Kuria. Harry's begeleidster komt regelmatig op bezoek en geeft de verpleegkundigen en arts van Kuria adviezen. Deze adviezen gaan bijvoorbeeld over het omgaan met Harry's alcoholverslaving, zijn behoefte aan eigen regie en zijn wens om in contact te blijven met vrienden die ook dakloos zijn. 
Klop, H., Dongen, S. van, Onwuteaka-Philipsen, B., Rietjens, J., Veer, A. de, Francke, A., Gootjes, J. Samen sterker: consultatie verbetert palliatieve zorg voor dak- en thuislozen. Pallium: 2018, 20(1), 16-19

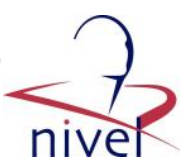

Kader 2. Aanpak onderzoek en deelnemers Hoe is het onderzoek aangepakt?

De focusgroepen waren onderdeel van een eenjarig project, gefinancierd door ZonMw, dat daarnaast bestond uit literatuuronderzoek, dossieronderzoek en een cohortstudie. Het was een samenwerking tussen VUmc, Erasmus MC, NIVEL, Hospice Kuria, Havenzicht Rotterdam, HVO Querido, Leger des Heils, Nederlandse Straatdokters en een ervaringsdeskundige. Er zijn vier focusgroepen met professionals en twee met mensen die dak- en thuisloos zijn (najaar 2016).

Wie deden mee aan de focusgroepen?

- verpleegkundigen (outreachend, sociaal-medisch, verpleeghuizen, hospice)

- artsen (kaderarts palliatieve zorg, verslavingsarts, GGD-arts, specialist ouderengeneeskunde)

- straat- of drugspastores

- beleidsadviseurs

- geestelijk verzorgers

- apothekers

- maatschappelijk werkers

- hospicecoördinatoren

- ervaringsdeskundigen

- personen verblijvend op een verpleegafdeling voor dak- en thuislozen. 
Klop, H., Dongen, S. van, Onwuteaka-Philipsen, B., Rietjens, J., Veer, A. de, Francke, A., Gootjes, J. Samen sterker: consultatie verbetert palliatieve zorg voor dak- en thuislozen. Pallium: 2018, 20(1), 16-19

\section{Kader 3. Onderwerpen voor consultatie en kennis}

- Multiproblematiek en diversiteit van de doelgroep. Bijvoorbeeld complexe somatische problemen in combinatie met verslaving of een licht verstandelijke beperking.

- Culturele en religieuze verschillen. Bijvoorbeeld inzicht in cultuur en religie zodat behoeften beter begrepen worden.

- Zorgmijding. Herkenning en omgaan met zorgmijding en -weigering.

- Ziektebeelden en diagnosticeren. Specifieke ziektebeelden die kenmerkend zijn voor een doelgroep in laatste levensfase.

- Pijnbehandeling. Bijvoorbeeld middelentolerantie vanwege verslavingsproblematiek.

- Bespreken van de palliatieve fase met de persoon die dak- of thuisloos is. Bespreking is soms lastig bijvoorbeelde vanwege angst voor de dood of het ontbreken van vertrouwen in de professional.

- Verslaving en middelengebruik. Kennis over hoe om te gaan met verslaving en middelengebruik en het verloop van de palliatieve fase.

- Verloop van het stervensproces. Het stervensproces is door bovenstaande onderwerpen vaak complex.

- Agressiviteit en gedragsproblemen. Veel professionals hebben weinig ervaring met agressiviteit en gedragsproblemen.

- Inzet van vrijwilligers. Advies over hoe vrijwilligers specifiek voor deze doelgroep kunnen worden ingezet.

- Nazorg voor professionals en medepatiënten. Voor professionals omdat zij intensieve zorg hebben verleend, voor de doelgroep vanwege het kleine netwerk dat zij hebben en hun relatie met medepatiënten.

- Uitvaart, herdenken en rituelen. Een waardig afscheid is erg belangrijk voor de doelgroep. De juiste vorm is vaak zoeken voor professionals. 